\title{
Kemampuan Berpikir Siswa dalam Menyelesaikan Soal HOTs pada Materi Pola dan Barisan Bilangan
}

\author{
${ }^{1 *}$ J. Junaidi, ${ }^{1}$ Yenita Roza, ${ }^{1}$ M. Maimunah \\ ${ }^{1}$ Program Studi Magister Pendidikan Matematika, FKIP, Universitas Riau, Jl. Kampus Bina Widya \\ KM 12.5 Pekanbaru 28293, Indonesia \\ *Corresponding Author e-mail: junaidi7056@grad.unri.ac.id \\ Received: June 2020; Revised: June 2020; Published: July 2020
}

\begin{abstract}
Abstrak
Pada abad 21 diperlukan keterampilan berpikir tingkat tinggi (HOTs) yang mencakup kemampuan berpikir kritis dan berpikir kreatif. Tujuan penelitian ini adalah untuk mendeskripsikan kemampuan interpretasi, analisis, inferensi, kelancaran dan orisinalitas siswa dalam menyelesaikan soal pola dan barisan bilangan. Metode yang digunakan dalam penelitian adalah deskriptif kualitatif dan subjek sebanyak 40 siswa yang terdiri 19 siswa SMPN 5 Bantan dan 21 Siswa MTS Al-Huda. Instrumen yang digunakan berupa (1) tes tertulis yang berorientasikan HOTs dan (2) pedoman wawancara. Hasil tes menunjukkan rata-rata HOTs siswa SMPN 5 Bantan $(49,34)$ dan MTS Al-Huda $(45,12)$ berkategori cukup. Skor tiap indikator HOTs untuk siswa SMPN 5 Bantan diketahui bahwa interpretasi $(48,68)$, analisis $(40,13)$, inferensi $(64,47)$, kelancaran $(52,68)$ dan orisinalitas $(40,79)$ sedangkan untuk siswa MTs Al-Huda adalah interpretasi $(61,18)$, analisis $(40,79)$, inferensi $(53,57)$, kelancaran $(38,16)$ dan orisinalitas $(45,24)$. Berdasarkan hasil wawancara juga diketahui bahwa rendahnya HOTs siswa dikarenakan siswa tidak terbiasa dalam menyelesaikan soal HOTs serta tidak tersedianya soal-soal HOTs yang secara khusus mengukur HOTs di sekolah, sehingga diharapkan adanya penelitian lebih lanjut mengenai soalsoal HOTs.
\end{abstract}

Kata Kunci: Keterampilan berpikir tingkat tinggi (HOTs), Pola dan Barisaan Bilangan

\section{Students' Thinking Ability in Solving HOTs Questions on Material Patterns and Rows of Numbers}

\begin{abstract}
In the 21st century, higher order thinking skills (HOTs) are needed which include critical thinking skills and creative thinking. The purpose of this study is to describe the students' ability of interpretation, analysis, inference, fluency and originality in solving questions about patterns and rows of numbers. The method used in this research is descriptive qualitative and as many as 40 students consisting of 19 students of SMPN 5 Bantan and 21 students of Al-Huda MTS. The instrument used in the form of (1) written tests oriented to HOTs and (2) interview guidelines. The test results showed the average level of SMPN 5 Bantan students' HOTs (49.34) and MTS Al-Huda (45.12) was categorized as sufficient. The score of each indicator of HOTs for SMPN 5 Bantan students is known that interpretation $=48.68$, analysis $=40.13$, inference $=64.47$, fluency $=52.68$ and originality $=$ 40.79 while for MTs Al-Huda students are interpretation $=61.18$, analysis $=40.79$, inference $=53.57$, fluency $=$ 38.16 and originality $=45.24$. Based on the interview results it is also known that the low level of students' HOTs is because students are not accustomed to solving HOTs questions and the unavailability of HOTs questions that specifically measure HOTs in schools, so it is hoped that further research on questions of HOTs.
\end{abstract}

Keywords: Higher order thinking skills (HOTs), Patterns and rows of numbers

How to Cite: Junaidi, J., Roza, Y., \& Maimunah, M. (2020). Kemampuan Berpikir Siswa dalam Menyelesaikan Soal HOTs pada Materi Pola dan Barisan Bilangan. Jurnal Penelitian dan Pengkajian Ilmu Pendidikan: e-Saintika, 4(2), 173-182. doi:https://doi.org/10.36312/e-saintika.v4i2.220 


\section{PENDAHULUAN}

Pada era globalisisasi atau abad 21 ini, sumber daya utama yang harus dimiliki adalah ketrampilan intelektual tingkat tinggi dimana kemampuan ini melibatkan penalaran yang logis, sistematis, kritis, cermat, dan kreatif. Kompetensi ini diperlukan untuk dapat meningkatkan kemampuan dalam menemukan, mengolah, dan memanfaatkan informasi agar dapat bertahan dalam permasalahan di dunia nyata maupun dunia kerja yang kompetitif dan dalam situasi yang tidak pasti (Depdiknas, 2006).

Matematika sebagai mata pelajaran memiliki peran penting dalam mempersiapkan generasi muda untuk menghadapi tantangan dikehidupan baik itu tantangan pribadi, pekerjaan dan sosial sehingga pelajaran matematika tidak hanya sekedar menghitung tatapi diharapkan lebih menekankan pada kemampuan berpikir. Kurniati dkk (2016) mengatakan bahwa Pemahaman matematika menjadi pusat dalam mempersiapkan generasi muda untuk hidup di masyarakat modern. Sehingga dengan mempelajari matematika siswa di tuntut bukan hanya sekedar menghitung akan tetapi lebih menekankan kepada keterampilan dalam menyelesaikan suatu permasalahan sehingga akan terbiasa dalam menghadapi tantangan-tantangan dunianyata, dengan demikian siswa akan lebih memaknai matematika dalam belajar. Sejalan dengan hal ini, Dosinaeng dkk (2019) mengatakan telah terjadi pergeseran perspektif terhadap matematika dari sekedar ilmu hitung menjadi sarana pembentuk kemampuan berpikir seseorang. Dengan demikian pelajaran matematika merupakan pelajaran yang ikut serta berkembang sejalan dengan perkembangan zaman.

Dalam pelajaran matematika diperlukan keterampilan berpikir. Keterampilan berpikir merupakan proses berpikir seseorang yang dituangkan kedalam tulisan. Irawati (2018) berpikir merupakan suatu aktivitas mental yang terjadi pada diri seseorang yang memiliki fungsi menjawab suatu permasalahan dan mengambil suatu keputusan, serta menemukan pemahaman. Terdapat dua tingkatan berpikir yaitu Kemampuan berpikir tingkat rendah dan kemampuan berpikir tingkat tinggi. Mahanal (2019) mengungkapkan bahwa kedua kemampuan berpikir tersebut memiliki hubungan yang erat sehingga kemampuan berpikir tingkat rendah sangat diperlukan untuk mencapai kemapuan berpikir tingkat tinggi.

Purbaningrum (2017) mengatakan kemampuan mengolah informasi dan gagasan dengan cara mengubah makna dan keterkaitannya, menyatukan data dengan gagasan untuk menyimpulkan, menjelaskan, menafsirkan, menggeneralisasi dan mensintesisnya merupakan bagian dari kemampuan berpikir tingkat tinggi. Sedangkan menurut Dosinaeng (2019) kemampuan berpikir tingkat tinggi adalah gabungan dari kemampuan berpikir kritis dan kemampuan berpikir kreatif. Seseorang yang berpikir secara kritis dan kreatif bisa menyelesaikan suatu permasalahan dengan lebih baik. Hal ini dikarenakan ia mampu memahami masalah yang dihadapinya secara mendalam sehingga mampu menyusun dan melaksanakan rencana penyelesaian secara rinci, dan bisa melihat kembali pekerjaan yang telah dilakukannya berdasarkan kemampuan dalam mengevaluasi dan mengatur diri sendiri. Karim (2015) menjelaskan indikator untuk mengukur kemampuan berpikir kritis adalah interpretasi, analisis, evaluasi dan inferensi. Menurut Moma (2016) indikator kemampuan berpikir kreatif dapat dilihat dari ketrampilan berpikir lancar, berpikir luwes, orisinal, elaborasi, dan ketrampilan menilai. Dengan demikian dapat dikatakan bahwa kemampuan berpikir tingkat tinggi adalah kemampuan memanipulasi informasi dan gagasan dengan cara kritis sehingga mampu 
memecahkan masalah secara kreatif.

Dalam mengukur kemampuan berpikir tingkat tinggi seseorang diperlukan instrumen yang mengacu pada indikator kemampuan berpikir tingkat tinggi. sehingga indikator kemampuan berpikir tingkat tinggi dalam penelitian ini merupakan gabuangan dari kemampuan berpikir kritis dan berpikir kreatif sebagai beikut (1) interpretasi yang ditunjukan dengan memberi makna data atau informasi dari permasalahan (2) analisis yang ditunjukan dengan memberikan analisis beserta argumen yang relevan dalam menyelesaikan masalah disertai langkah-langkah (3) inferensi yang merupakan kemampuan dalam memperoleh hal-hal yang diperlukan untuk membuat suatu kesimpulan (4) kelancaran/fluency yang ditunjukkan dengan menuliskan jawaban lebih dari satu cara dengan tepat (5) orisinilitas yang ditunjukkan dengan memberikan jawaban dengan caranya sendiri (tidak biasanya)

Kemampuan berpikir tingkat tinggi siswa perlu dikembangakan demi mendapatkan sumber daya manusia yang memiliki kompetensi dan daya saing. Menurut Sumaryanta (2018), guru mempunyai peran penting dalam mengembangkan dan mengevaluasi HOTS siswa. Hal ini disebabakan guru yang berperan dalam membentuk pola pikir siswa dengan menjadikan siswa sebagai pusat pembelajaran. Adapun cara yang bisa digunakan oleh guru untuk mengukur dan meningkatkan kemampuan berpikir tingkat tinggi siswa dengan memberikan soal-soal HOTS (Wicasari, 2016). Tujuan yang akan dicapai melalui penelitian yaitu untuk mengidentifikasi dan mendeskripsikan Kemampuan berpikir tingkat tinggi siswa.

\section{METODE}

Metode yang digunakan pada Penelitian ini yaitu deskriptif kualitatif. Topik yang akan dideskripsikan adalah kemampuan berpikir tingkat tinggi siswa dalam menyelesaikan soal HOTS pada meteri pola dan barisan bilangan. Analisis data dalam penelitian ini lebih menekankan makna dari generalisasi. Makna yang dimaksud adalah data yang sebenarnya yang diperoleh dari penelitin yang merupakan nilai siswa dalam menyelesaikan soal HOTS.

Tahapan dalam penelitian ini adalah (1) meryusun instrumen tes (2) melakukan uji coba (3) menghitung validitas, reliabelitas, tingkat kesukaran dan daya (4) mengujicobakan soal (5) menilai hasil jawaban berdasarkan indikator (6) mendeskripsikan kemampuan berpikir tingkat tinggi siswa

Subjek berjumlah 40 orang yang merupakan 19 orang siswa SMP N 5 Bantan dan 21 Orang siswa MTS Al-Huda. Instrumen yang digunakan pada penelitian ini berupa tes tertulis yang beorientasikan kemampuan berpikir tingkat tinggi dan wawancara. Adapuan Wawancara yang dilakukan terhadap guru matapelajaran matematika berhubungan dengan soal yang digunakan pada saat latihan dan ulangan. Soal yang digunakan berjumlah 5 soal dengan kategori valid dan reliabel. Adapun kevalidan dan reliabilitas soal dapat dilihat pada Tabel 1 berikut.

Tabel 1. Validitas dan reliabilitas soal yang digunakan

\begin{tabular}{ccccc}
\hline No Soal & Validitas & Reliabelitas & Tingkat Kesukaran & Daya Beda \\
\hline 1 & 0,95 & & Sedang & Baik \\
2 & 0,94 & & Sedang & Baik \\
3 & 0,92 & 0,736 & Sedang & Baik \\
4 & 0,81 & & Sedang & Baik \\
5 & 0,89 & & Sulit & Baik \\
\hline
\end{tabular}


Berdasarkan perhitungan reliabilitas terhadap 5 butir soal yang digunakan bahwa indeks Reliabilitasnya adalah 0,736 sehingga tes keterampilan berpikir tingkat tinggi layak digunakan. Tes dikatakan reliabel jika koefesien indeks reliabilitas tes $>70$. Dengan menggunakan tes ini diharapkan tergambarkan kemampuan berpikir tingkat tinggi yang dimiliki oleh siswa. Berikut adalah kategori skor keterampilan berpikir tingkat tinggi siswa (Tabel 2).

Tabel 2. Kategorisasi Skor Keterampilan Berpikir Tingkat Tinggi (Purbaningrum, 2017)

\begin{tabular}{cc}
\hline Nilai Siswa & Kategori \\
\hline $81-100$ & Sangat Baik \\
$61-80$ & Baik \\
$41-60$ & Cukup \\
$21-40$ & Kurang \\
$<20$ & Sangat Kurang \\
\hline
\end{tabular}

\section{HASIL DAN PEMBAHASAN}

Setelah mengikuti pembelajaran matematika di sekolah, siswa diharapkan memiliki kemampuan berpikir tingkat tinggi. Jika seseorang memiliki kemampuan berpikir tingkat tinggi maka akan bisa bertahan terhadap permasalahan dunia nyata karena mampu melihat permasalahan secara kritis dan menemukan solusi secara kreatif. Sebaran data keterampilan berpikir tingkat tinggi siswa dari hasil tes yang dilakukan di sekolah disajikan pada Gambar 1.

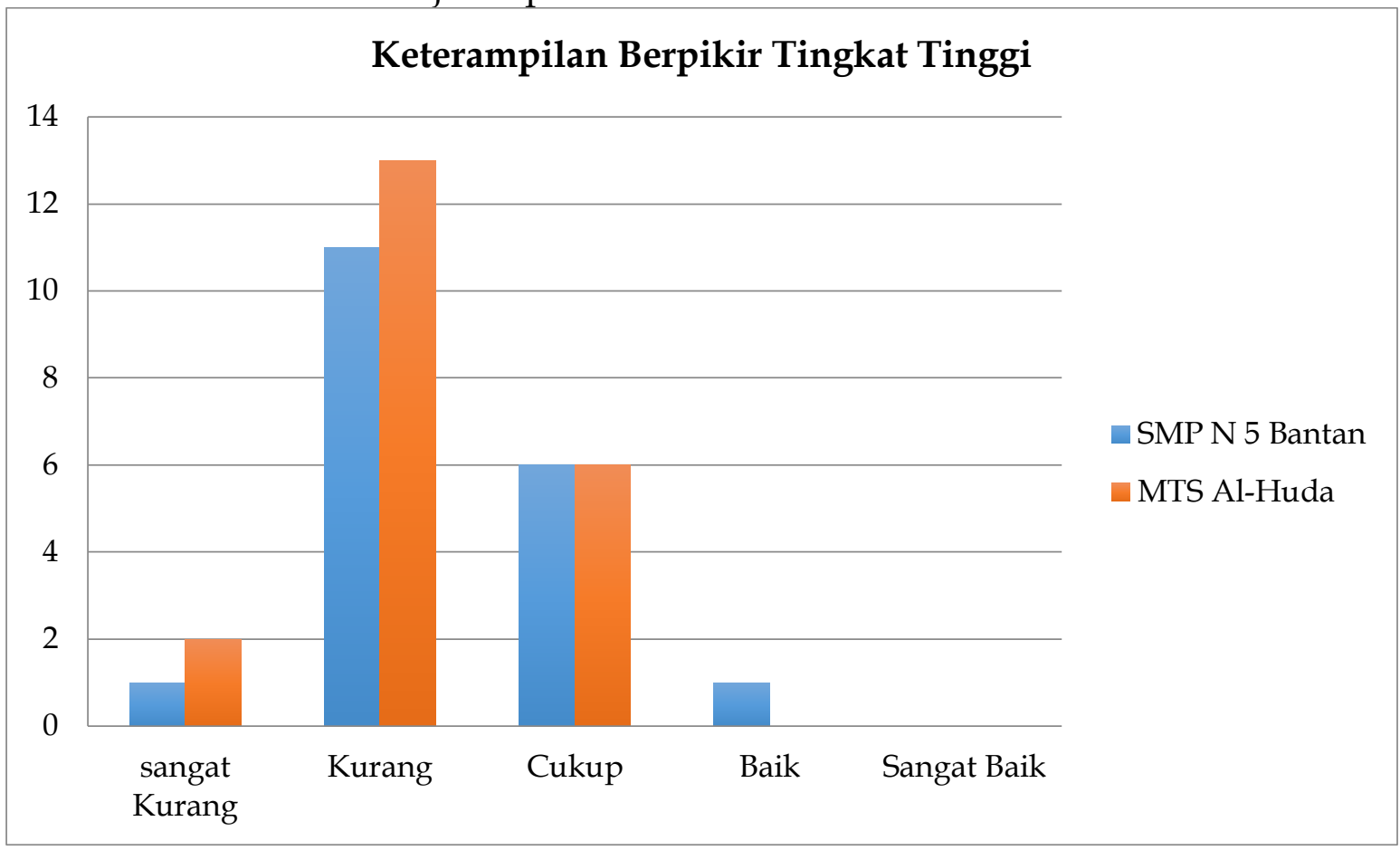

Gambar 1. Grafik keterampilan berpikir tingkat tinggi

Berdasarkan Gambar 1, diketahui bahwa pada SMP N 5 Bantan, siswa yang memiliki Keterampilan berpikir pada kategori sangat kurang 1 Orang $(5,2 \%)$, siswa dengan tingkat keterampilan yang Kurang adalah 11 orang (57,8\%), siswa dengan tingkat Keterampilan Cukup 6 Orang (31,6\%) dan siswa dengan tingkat Keterampilan Baik 1 Orang (5,2\%). Sedangkan pada sekolah MTS Al-Huda Tidak Terdapat siswa yang mempunyai Kemampuan yang sangat baik, siswa dengan tingkat keterampilan Sangat Kurang Baik 2 Orang (9,5\%), siswa dengan tingkat keterampilan Kurang 13 
Orang (61,9\%), siswa dengan tingkat keterampilan Cukup 6 Orang (28,5\%) dan tidak terdapat siswa yang memiliki tingkat keterampilan Baik maupun Sangat Baik. Sedangkan kemampuan berpikir siswa dalam menyelesaikan soal HOTS pada tiaptiap indikator terlihat pada Tabel 3 berikut.

Tabel 3. Sebaran data siswa pada indikator Interpretasi

\begin{tabular}{|c|c|c|c|}
\hline \multirow[b]{2}{*}{ Indikator } & \multirow[b]{2}{*}{ Keterangan } & \multicolumn{2}{|c|}{ Banyak Siswa } \\
\hline & & SMPN 5 & $\begin{array}{l}\text { MTS Al- } \\
\text { Huda }\end{array}$ \\
\hline \multirow{5}{*}{$\begin{array}{l}\text { Interpretasi } \\
\text { (menulsikan } \\
\text { hal-hal yang } \\
\text { diketahui } \\
\text { dan ditanya) }\end{array}$} & $\begin{array}{l}\text { Tidak menulis yang diketahui dan yang } \\
\text { ditanyakan. }\end{array}$ & 1 & 1 \\
\hline & $\begin{array}{l}\text { Menulis diketahui dan ditanya tetapi tidak } \\
\text { sesuai dengan soal }\end{array}$ & 5 & 1 \\
\hline & $\begin{array}{l}\text { Menulis diketahui saja atau yang } \\
\text { ditanyakan saja denga benar. }\end{array}$ & 4 & 7 \\
\hline & $\begin{array}{l}\text { Menulis diketahui dan ditanya dengan } \\
\text { benar akan tetapi belum lengkap }\end{array}$ & 6 & 11 \\
\hline & $\begin{array}{l}\text { Menulis diketahui dan ditanya sesuai } \\
\text { dengan konteks soal dengan benar dan } \\
\text { lengkap }\end{array}$ & 3 & 1 \\
\hline
\end{tabular}

Indikator interpretasi yang ditunjukkan dengan memberi makna data atau informasi dari permasalahan dengan baik dengan membuat informasi apa yang diketahui dan ditanya dari soal cerita yang diberikan dengan lengkap. Berdasarkan Tabel 3, terdapat 1 siswa SMP dan 1 siswa MTS yang tidak menuliskan yang diketahui dan ditanya dari permasalahan yang diberikan, 5 siswa SMP dan 1 siswa MTs yang menuliskan diketahui dan ditanya tetapi masih belum tepat, 4 siswa SMP dan 7 siswa MTS yang hanya menulis diketahui saja atau yang ditanya dengan benar, 6 siswa SMP dan 11 siswa MTS yang menuliskan diketahui dan ditanya namun belum lengkap serta terdapat 3 siswa SMP dan 1 Siswa MTS yang menulis diketahui dan ditanyakan dengan tepat dan lengkap. Secara keseluruhan kemampuan interpretasi yang dimiliki oleh siswa SMPN 5 adalah 56,57\% dan kemampuan interpretasi yang dimiliki oleh siswa MTs adalah 61,90\%. Kemampuan Interpretasi yang dimiliki oleh siswa SMP berada pada kategori cukup sedangkan kemampuan interpretasi siswa MTS pada kategori baik. Sebaran kemampuan menganalisis siswa disajikan pada Tabel 4. Tabel 4. Sebaran data siswa pada indikator menganalisis

\begin{tabular}{|c|c|c|c|}
\hline \multirow[b]{2}{*}{ Indikator } & \multirow[b]{2}{*}{ Keterangan } & \multicolumn{2}{|c|}{ Banyak Siswa } \\
\hline & & SMPN 5 & $\begin{array}{l}\text { MTS Al- } \\
\text { Huda }\end{array}$ \\
\hline Menganalisis & Tidak memberikan analisis & 0 & 3 \\
\hline Memberikan & Memberikan analisis tetapi salah & 6 & 6 \\
\hline $\begin{array}{l}\text { analisis dengan } \\
\text { memberikan }\end{array}$ & $\begin{array}{l}\text { Memberikan analisis yang salah } \\
\text { tetapi cocok dengan soal }\end{array}$ & 12 & 7 \\
\hline $\begin{array}{l}\text { argumen yang } \\
\text { relevan dalam } \\
\text { penyelesaian }\end{array}$ & $\begin{array}{l}\text { Memberikan analisis dengan benar } \\
\text { dan cocok dengan soal tetapi belum } \\
\text { lengkap }\end{array}$ & 1 & 5 \\
\hline $\begin{array}{l}\text { masalah disertai } \\
\text { langkah } \\
\text { penyelesaian }\end{array}$ & $\begin{array}{l}\text { Memberikan analisis dengan benar } \\
\text { dan sesuai soal dengan lengkap }\end{array}$ & 0 & 0 \\
\hline
\end{tabular}


Indikator analisis yaitu memberikan analisis dengan memberikan argumen yang relevan dalam penyelesaian masalah disertai langkah-langkah penyelesaian. Berdasarkan Tabel 4, tidak terdapat siswa SMP dan 3 siswa MTS yang tidak memberikan analisis dan terdapat 6 siswa SMP dan MTS yang memberikan analisis namun tidak tepat dan tidak sesuaikam dengan soal. Terdapat 12 siswa SMP dan 7 siswa MTS yang membuat analisis yang salah akan tetapi sudah sesuai soal dan terdapat 1 siswa SMP dan 5 siswa MTS yang membuat analisis dengan benar dan sesuai soal tetapi belum lengkap serta tidak terdapat siswa SMP maupun siswa MTS yang telah mampu memberikan analisis dengan tepat sesuai soal dengan lengkap. Secara keseluruhan persentase Analisis yang dimiliki oleh siswa SMP dan MTS yaitu 43,42\% dan 41,66 \%. Kemampuan Analisis siswa SMP dan MTS berada pada kaegori Cukup. Hal ini menjunjukkan bahwa kemampuan siswa yang ditunjukan dengan memberikan analisis beserta argumen yang relevan dalam menyelesaikan masalah disertai langkah-langkah masih rendah.

Tabel 5. Sebaran data siswa pada indikator Inferensi

\begin{tabular}{|c|c|c|c|}
\hline \multirow[b]{2}{*}{ Indikator } & \multirow[b]{2}{*}{ Keterangan } & \multicolumn{2}{|c|}{ Banyak Siswa } \\
\hline & & SMPN 5 & $\begin{array}{l}\text { MTS Al- } \\
\text { Huda }\end{array}$ \\
\hline \multirow{5}{*}{$\begin{array}{l}\text { Melakukan } \\
\text { pengecekan/ } \\
\text { Inferensi } \\
\text { (Membuat } \\
\text { kesimpulan) }\end{array}$} & Tidak menuliskan kesimpulan . & 1 & 3 \\
\hline & $\begin{array}{l}\text { Menuliskan kesimpulan tetapi masih } \\
\text { salah }\end{array}$ & 1 & 0 \\
\hline & $\begin{array}{l}\text { Menuliskan kesimpulan yang salah } \\
\text { tetapi sesuai soal. }\end{array}$ & 6 & 10 \\
\hline & $\begin{array}{l}\text { Menulis kesimpulan secara benar, } \\
\text { tetapi belum lengkap. }\end{array}$ & 8 & 7 \\
\hline & $\begin{array}{l}\text { Menulis kesimpulan dengan benar, dan } \\
\text { lengkap }\end{array}$ & 3 & 1 \\
\hline
\end{tabular}

Indikator Inferensi seperti terlihat pada Tabel 5, terdapat 1 orang siswa SMP dan 3 siswa MTS yang tidak menuliskan kesimpulan, terdapat 1 siswa SMP dan tidak terdaapat siswa MTS yang menuliskan kesimpulan tetapi masih salah, terdapat 6 siswa SMP dan 10 Siswa MTS yang menulis kesimpulan yang salah tepati sesuaikan soal, terdapat 8 siswa SMP dan 7 siswa MTS yang menulis kesimpulan dengan tetapi belum lengkap serta terdapat 3 siswa SMP dan 1 siswa MTS yang telah mampu mnulis kesimpulan dengan benar dan lengkap. Secara keseluruhan, pada indikator Inferensi Keterampilan yang dimiliki oleh siswa SMP dan Siswa MTS adalah 64,47\% dan 53,57\%. Pada indikatr Inferensi, kemampuan yang dimiliki oleh siswa SMP berada pada kategori Baik dak kemampuan Inferensi siswa MTS merupakan kategori Cukup.

Tabel 6. Sebaran data siswa pada indikator Kelancaran

\begin{tabular}{|c|c|c|c|}
\hline \multirow[b]{2}{*}{ Indikator } & \multirow[b]{2}{*}{ Keterangan } & \multicolumn{2}{|c|}{ Banyak Siswa } \\
\hline & & SMP N 5 & $\begin{array}{l}\text { MTS Al- } \\
\text { Huda }\end{array}$ \\
\hline Kelancaran & Tidak menuliskan jawaban & 0 & 2 \\
\hline $\begin{array}{l}\text { (membuat } \\
\text { penyelesaian }\end{array}$ & $\begin{array}{l}\text { Menuliskan jawaban yang tidak sesuai } \\
\text { dengan soal }\end{array}$ & 2 & 9 \\
\hline $\begin{array}{l}\text { lebih dari } \\
\text { satu ide) }\end{array}$ & $\begin{array}{l}\text { Menuliskan jawaban yang sesuai soal } \\
\text { tetapi penyelesainnya masih salah. }\end{array}$ & 10 & 8 \\
\hline
\end{tabular}




\begin{tabular}{llcc}
\hline \multirow{2}{*}{ Indikator } & \multicolumn{1}{c}{ Keterangan } & \multicolumn{2}{c}{ Banyak Siswa } \\
SMP N 5 & $\begin{array}{c}\text { MTS Al- } \\
\text { Huda }\end{array}$ \\
\cline { 2 - 4 } & $\begin{array}{l}\text { Menuliskan jawaban lebih dari satu } \\
\text { penyelesaian tetapi penyelesaiannya } \\
\text { belum tepat }\end{array}$ & 6 & 2 \\
$\begin{array}{l}\text { Menuliskan jawaban lebih dari satu } \\
\text { penyelesaian yang sesuai dan idenya } \\
\text { benar dan tepat }\end{array}$ & 1 & 0 \\
\hline
\end{tabular}

Indikator Kelancaran seperti disajikan pada Tabel 6 terlihat bahwa tidak terdapat siswa SMP dan terdapat 2 siswa MTS yang tidak menjawab atau memberikan ide dari suatu permasalahan, terdapat 2 siswa SMP dan 9 siswa MTS yang memberikan ide dalam menjawab soal namun tidak relevan dengan pemecahan masalah, terdapat 10 siswa SMP dan 8 siswa MTS yang memberikan sebuah ide yang relevan dengan permasalahan namun jawaban masih salah dan terdapat 6 siswa SMP dan 2 Siswa MTS yang memberikan ide lebih dari 1 satu cara tetapi jawaban masih salah serta terdapat 1 siswa SMP yang menuliskan jawaban lebih dari satu idenya dengan benar dan tepat. Kemampuan berpikir tingkat tinggi siswa pada indikator Inferensi pada siswa SMP adalah 40.01 \% sedangkan pada siswa MTS 36,90\%. Kemampuan Kelencaran siswa SMP dan MTS berada pada kategori Cukup. Hal ini menunjukkan bahawa kemampuan siswa dalam memberikan jawaban dengan berbagai cara masih rendah. Rendahnya keterampilan Kelancaran yang dimiliki siswa dapat dilihat dari lembar jawaban siswa yang menjawab hanya dengan 1 cara. Hanya beberapa dari siswa SMP N 5 dan MTS menjawab dengan lebih dari satu cara.

Tabel 7. Sebaran data siswa pada indikator Keaslian

\begin{tabular}{|c|c|c|c|}
\hline \multirow{3}{*}{ Indikator } & \multirow{3}{*}{ Keterangan } & \multicolumn{2}{|c|}{ Banyak Siswa } \\
\hline & & SMPN & MTS \\
\hline & & 5 & Al-Huda \\
\hline \multirow{5}{*}{$\begin{array}{l}\text { Keaslian } \\
\text { (Memberi } \\
\text { penyelesian } \\
\text { dengan } \\
\text { caranya } \\
\text { sendiri) }\end{array}$} & Tidak menjawab & 0 & 3 \\
\hline & Menuliskan penyelesaian dengan cara & 7 & 3 \\
\hline & $\begin{array}{l}\text { Menuliskan penyelesaian dengan cara } \\
\text { sendiri, perhitungan terarah akan tetapi } \\
\text { belum lengkap }\end{array}$ & 12 & 10 \\
\hline & $\begin{array}{l}\text { Menuliskan penyelesaian dengan cara } \\
\text { sendiri akan tetapi masih keliru dalam } \\
\text { perhitungan sehingga jawaban salah. }\end{array}$ & 0 & 5 \\
\hline & $\begin{array}{l}\text { Menuliskan penyelesaian dengan cara } \\
\text { sendiri, proses perhitungan dan hasilnya } \\
\text { benar }\end{array}$ & 0 & 0 \\
\hline
\end{tabular}

Indikator Orisinilitas seperti terlihat pada Tabel 7, terlihat bahwa tidak terdapat siswa SMP yang tidak menjawab dan terdapat 3 siswa MTS yang tidak menjawab, terdapat 7 siswa SMP dan 3 siswa MTS yang memberikan penyelesaian tetapi tidak dapat dipahami, terdapat 12 siswa SMP dan 10 siswa MTS yang memberikan penyelesaian dengan cara sendiri, perhitungan terarah akan tetapi belum lengkap serta tidak terdapat siswa SMP dan 5 Siswa MTS yang menuliskan penyelesaian 
dengan caranya sendiri akan tetapi keliru dalam perhitungan sehingga jawaban salah. secara keseluruhan pada indikator orisinilitas terlihat keterampilan berpikir tingkat tinggi yang dimiliki siswa SMP yaitu 40,78\% sedangkan pada siswa MTS 45,23\%. Pada indikator Orisinilitas siswa SMP dan MTS berada pada kategori Cukup. Hal ini menujukkan kemampuan siswa dalam Memberikan jawaban dengan caranya sendiri (tidak biasanya) masih rendah. Secara umum keterampilan berpikir siswa pada tiap indikator disajikan secara singkat pada Gambar 2.

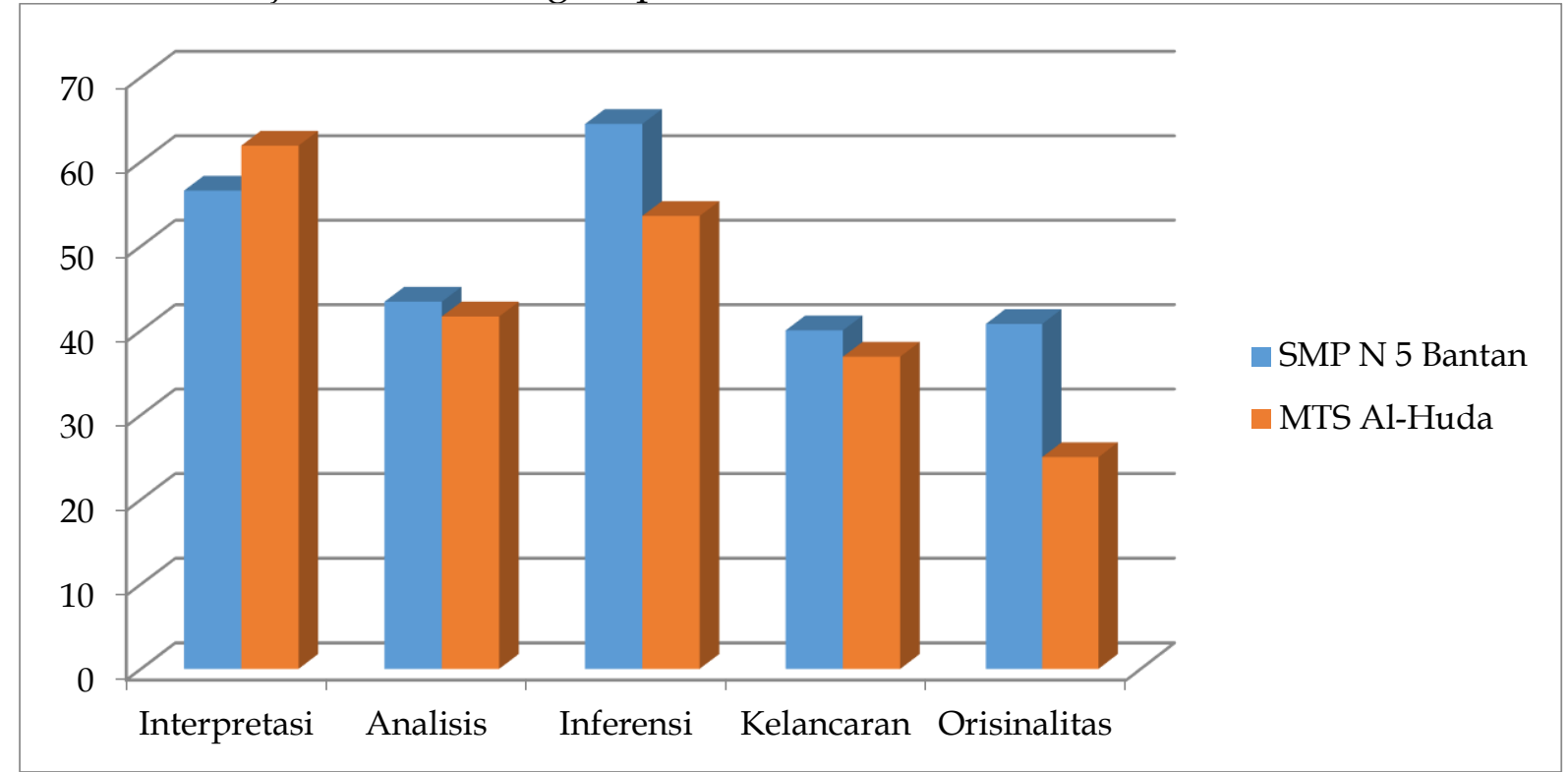

Gambar 2. Persentase Keterampilan berpikir tingkat tinggi pada tiap indikator

Berdasarkan Gambar 2 diketahui bahwa rata-rata kemampuan berpikir tingkat tinggi siswa SMP N 5 dan siswa MTS Al-Huda adalah 49,34 dan 45,12. Rata-rata ini tergolong Rendah. Sejalan dengan pendapat tersebut, Irawati (2018) juga mengatakan bahwa kemampuan berpikir tingkat tinggi siswa masih rendah hal ini dikarenakan siswa tidak terbiasa dalam menyelesaikan soat HOTS. Hal ini bertentangan dengan hasil penelitian yang telah dilakukan oleh Fariah dkk (2016) yang mengatakan bahwa kemampuan berpikir tingkat tinggi siswa berada pada kategori Baik.

Rendahnya keterampilan berpikir yang dimiliki oleh siswa SMP N 5 Bantan dan MTs Al-Huda ini membuat peneliti melakukan wawancara terhadap guru matapelajaran matematika di kedua sekolah tersebut. Bedasarkan hasil wawancara tentang soal-soal yang digunakan pada saat pelajaran diketahui bahwa soal yang digunakan berasal dari buku paket. Guru tidak pernah menggembangkan sendiri soal yang secara khusus untuk mengukur keterampialan berpikir yang dimiliki siswa. Dengan demikian diketahui bahwa soal yang digunakan lebih cendrung melatih pemahaman siswa akan konsep dan kurang dalam melatih kemampuan berpikir tingkat tinggi. Sedangkan bedasarkan hasil wawancara guru pelajaran matematika di sekolah MTS Al-Huda mengenai soal yang digunakan saat latihan dan uangan harian diketahui bahwa dalam melakukan tes baik itu ulangan atau latihan, guru hanya menggunakan soal-soal yang terdapat pada buku serta terkadang mencari soal yang ada di internet. Tidak tersedinya soal soal yang secara khusus untuk mengukur keterampilan yang dimiliki siswa serta guru tidak pernah mencoba mengembangkan soal-soal yang secara khusus mengukur keterampialn berpikir tingkat tinggi siswa serta. Sejalan dengan pendapat Budiman (2014) masalah yang terjadi disekolah, soalsoal yang diberikan baik itu dalam latihan maupun ulangan lebih banyak menguji aspek ingatan akan tetapi kurang dalam melatih kekampuan berpikir tingkat tinggi. 


\section{KESIMPULAN}

Dari hasil penelitian yang berupa analisis data serta wawancara maka kesimpulan yang diperoleh dari penelitian ini adalah Keterampilan berpikir tingkat tinggi siswa SMP N 5 tergolong pada kategori Cukup yakni 49,34 dengan indikator keterampilan berpikir tingkat tingginya yaitu Interpretasi $(48,68)$, Analisis $(40,13)$, Inferensi ( 64,47), Kelancaran $(52,68)$ dan Orisinalitas $(40,79)$. Kemampuan berpikir tingkat tinggi siswa MTs Al-Huda tergolong Cukup yakni 38,95 dengan indikator keterampilan berpikir tingkat tingginya yaitu Interpretasi $(61,18)$, Analisis $(40,79)$, Inferensi (53,57), Kelancaran $(38,16)$ dan Orisinalitas $(45,24)$. Berdasarkan hasil wawancara terhadap guru matematika disekolah SMP N 5 Bantan dan MTs Al-Huda diketahui bahwa rendahnya keterampilan berpikir tingkat tinggi siswa disebabkan siswa kurang terlatih dalam mengerjakan soal Kemampuan berpikir tingkat tinggi, selain itu tidak tersedianya soal-soal yang secara khusus dapat melatih keterampilan berpikir siswa yang dapat digunakan oleh guru.

\section{SARAN}

Berdasarkan hasil penelitian yang telah dilakukan, diharapkan pada guru mata pelajaran matematika khususnya di tingkat SMP/MTs bisa mengembangkan soalsoal kemampuan berpikir tingkat tinggi secara mandiri. Soal-soal yang dikembangkan dapat digunakan baik dalam latihan ataupun ulangan harian bahkan ujian semester sehingga siswa akan terbisa dalam menghadapi soal-soal kemampuan berpikir tingkat tinggi.

\section{UCAPAN TERIMA KASIH}

Peneliti mengucapkan terimaksih kepada berbagai pihak yang ikut terlibat dalam penelitian ini terutama pada Kepala Sekolah SMP N 5 Bantan dan Kepala Sekolah MTs Al-huda serta guru mata pelajaran Matematika di Sekolah SMP N 5 Bantan dan MTs Al-Huda.

\section{DAFTAR PUSTAKA}

Budiman, A., Jailani. (2014). Pengembangan Instrumen Asesment Higher Order Thinking Skill (HOTS) Pada Mata Pelajaran Matematika SMP Kelas VIII Semestr I. Jurnal Riset Pendidikan Matematika. 1(2), 39-150.

Dosinaeng, W. B. N. (2019). Analysis of students' higher order thinking skills in solving basic combinatorics problems. Math Didactic: Jurnal Pendidikan Matematika, 5(2), 133-147.

Dosinaeng, W.B N , Samuel Igo Leton, Meryani Lakapu (2019). Kemampuan Mahasiswa dalam Menyelesaikan Masalah Matematis Berorientasi HOTS. Jurnal Nasional Pendidikan Matematika, 3(1), 250-264.

Efendi, R. (2017). Konsep Revisi Taksonomi Bloom Dan Implementasinya Pada Pelajaran Matematika Smp. Jurnal Ilmiah Pendidikan Matematika, 2(1), 72-78.

Farihah, N., Imanah, U,N., Hidayati, E.W. (2018). Pengembangan Soal Higher Order Thinking Skills Pada Materi Barisan dan Deret Bilangan. Majamath, 1(2), 142-154. Irawati, T. N. (2018). Analisis Kemampuan Berpikir Tingkat Tinggi Siswa SMP Dalam Menyelesaikan Soal Pemecahan Masalah Matematika Pada Bilangan Bulat. Jurnal Gammat, 3(2), 1-7.

Karim \& Normaya. (2015). Kemampuan Berpikir Kritis Siswa Dalam Pembelajaran Matematika Dengan Menggunakan Model Jucama di Sekolah Menengah Pertama. Edu-Math, 3(1), 92-104. 
Kurniati, D., Harimukti,R., Nur Asiyah Jamil. (2016). Kemampuan Berpikir Tingkat Tinggi Siswa Smp Di Kabupaten Jember Dalam Menyelesaikan Soal Berstandar Pisa. Jurnal Penelitian dan Evaluasi Pendidikan, 20(20), 142-155.

Mahanal, S. (2019). Assasmen Keterampilan Berpikir Tingkat Tinggi. Jurnal Penelitian dan Pengkajian Ilmu Pendidikan e;Saintika, 3(2), 51-73.

Moma, L. (2015). Pengembangan Instrumen Penilaian Kemampuan Berpikir Kreatif Untuk Siswa SMP. Delta-Pi, 4(1), 27-41.

Prasetyani, E., Hartono, Y., \& Susanti, E. (2016). Kemampuan Berpikir Tingkat Tinggi Siswa Kelas Xi Dalam Pembelajaran Trigonometri Berbasis Masalah Di Sma Negeri 18 Palembang. Jurnal Gantang, 1(1), 31-40.

Purbaningrum, K. A. (2017). Kemampuan Berpikir Tingkat Tinggi Siswa SMP Dalam Memecahkan Masalah Matematika Ditinjau Dari Gaya Belajar. JPPM, 10(2), 4049.

Sumaryanta. (2018). Penilaian HOTs dalam Pembelajaran Matematika. Indonesian Digital Journal of Mathematics and Education, 8(8), 500-509.

Wicasari, B dan Zeny Ernaningsih. (2016). Analisis Kemampuan Berpikir Siswa Dalam Menyelesaikan Permasalahan Matematika Yang Berorientasi Pada HOTS. Prosiding Seminar Nasional Reforming Peagogy. 